suggest that the $A_{2 A}$ receptor is the major subtype accounting for adenosine-induced mast cell tPA activity. Finally, the supernatant from HMC-1 cells treated with adenosine (24h) significantly increased fibrin clot lysis, while ZM241385, an $\mathrm{A}_{2 \mathrm{~A}}$ receptor antagonist, abolished this effect. This study provides the first data to demonstrate the potentiating effect of adenosine on mast cell tPA activity and fibrin clot lysis.

\section{P183 GLOBAL BURDEN OF ALLERGIC BRONCHOPULMONARY ASPERGILLOSIS (ABPA) COMPLICATING ASTHMA}

doi:10.1136/thx.2010.151043.34

${ }^{1} \mathrm{D}$ W Denning, ${ }^{2} \mathrm{~A}$ Pleuvry, ${ }^{3} \mathrm{D} \mathrm{C}$ Cole. ${ }^{1}$ The University of Manchester, Manchester, UK; ${ }^{2}$ Oncalex, High Peak, Derbyshire, UK; ${ }^{3}$ Dalla Lana School of Public Health, University of Toronto, Toronto, Canada

Background ABPA may complicate asthma in some patients. The potential global ABPA burden remains unknown, limiting its prioritisation for both population and clinical responses.

Methods We estimated the number of adults with asthma, using the GINA statistics as the baseline dataset and this derived equation: Adult Prevalence $(\mathrm{AP})=$ total prevalence $\times$ adult population $/(0.88$ paediatric population + adult population). This method provided results which were compatible with more direct sources on Scotland (Ananadan, 2010), North Africa (Nafti, 2009) and the USA (CDC stats, 2008). Two period prevalence rates available on ABPA in asthmatic patients are $0.72 \%$ (Ireland; Donnelly, 1991) and 3.5\% (New Zealand; Eaton, 2000) (eliminating the non-classical cases from both papers) so we used a mean of $2.1 \%$ (range $0.72-3.5 \%$ ). We estimated case burdens by WHO region and for the UK and USA.

Results By WHO region, the ABPA burden estimates are: Europe, 466891 (range 160 077-778 152); Americas, 704926 (range 2416891174877); Eastern Mediterranean, 187963 (range 64 444-313272); Africa, 294058 (range 100820-490 097); Western Pacific, 881860 (range 302 352-1469 766); South East Asia, 614353 (range $210635-$ 1023 922); and global, 3150052 (range $1080018-5250086$ ) cases. The UK adult asthma and ABPA burdens are estimated to be $7.1 \mathrm{M}$ and 149901 (range 51395-249835) cases, respectively, with those for the US being 24.5M and 515787 (range 176841-859645) cases.

Conclusions ABPA is probably more common globally than has been appreciated. A lack of sufficient population research using current fungal diagnostic approaches and clinical research on antifungal therapy effects on the course of ABPA among different populations, limits our estimates' utility.

\section{P184 CAN WE PREDICT ASTHMA EXACERBATIONS IN WORKING- AGE ADULTS?}

doi:10.1136/thx.2010.151043.35

${ }^{1} \mathrm{~S} J$ MacNeill, ${ }^{1} \mathrm{~A}$ B Jones, ${ }^{2} \mathrm{C}$ J P Smith, ${ }^{2} \mathrm{R}$ Hubbard, ${ }^{1} \mathrm{P}$ Cullinan. ${ }^{1}$ National Heart and Lung Institute (Imperial College), London, UK; ${ }^{2}$ Division of Epidemiology and Public Health (University of Nottingham), Nottingham, UK

Introduction Little information exists on the prevalence and risk factors of asthma exacerbations in the general population. We used GP records to determine whether we can predict exacerbations in adults from their medical history.

Methods Using the Health Improvement Network database, weidentified all patients aged $16-40$ years with "current asthma" ( $\geq 1$ asthma prescription between $01 / 07 / 98$ and $01 / 07 / 00$ ). Three types of asthma exacerbations were studied: "hospital" defined as events resulting in attendance at A\&E or admission; "GP" defined as events occurring during out-of-hours consultations; and "prednisolone" defined as non-repeat prescriptions of oral prednisolone for asthma.
Results 73462 patients were identified. They were on average 28 years old and $56 \%$ were female. $36,762(50 \%)$ were registered for at least 5 years pre-qualification and 1 year post. Of these, $0.3 \%$ had at least one hospital exacerbation in the first year post, $2.4 \%$ had at least one GP exacerbation and $8.3 \%$ had at least one prednisolone exacerbation. Women and those prescribed a reliever and preventor at qualification were more likely to have exacerbations (see Abstract P184 Table 1). The prevalence of exacerbations was associated with an increasing number and increasingly recent history of exacerbations pre-qualification.

Abstract P184 Table 1 Prevalences of at least one exacerbation in the first year post-qualification

\begin{tabular}{|c|c|c|c|}
\hline & Hospital & GP & Prednisolone \\
\hline \multicolumn{4}{|l|}{ Sex } \\
\hline Male & $0.2 \%$ & $2.1 \%$ & $7.1 \%$ \\
\hline \multirow[t]{2}{*}{ Female } & $0.4 \%$ & $2.6 \%$ & $9.2 \%$ \\
\hline & $p=0.001$ & $p=0.001$ & $\mathrm{p}<0.001$ \\
\hline \multicolumn{4}{|l|}{ Prescriptions at qualification } \\
\hline Reliever and preventor & $0.5 \%$ & $3.9 \%$ & $14.3 \%$ \\
\hline \multirow[t]{2}{*}{ Other } & $0.3 \%$ & $1.7 \%$ & $5.8 \%$ \\
\hline & $\mathrm{p}=0.001$ & $\mathrm{p}<0.001$ & $\mathrm{p}<0.001$ \\
\hline \multicolumn{4}{|c|}{ Number of exacerbations* in the 5 years pre-qualification } \\
\hline \multicolumn{4}{|c|}{0} \\
\hline 1 & $0.3 \%$ & $1.7 \%$ & $5.9 \%$ \\
\hline 2 & $3.3 \%$ & $9.0 \%$ & $14.9 \%$ \\
\hline \multirow[t]{3}{*}{$3+$} & $17.5 \%$ & $12.5 \%$ & $25.0 \%$ \\
\hline & $18.8 \%$ & $30.8 \%$ & $47.8 \%$ \\
\hline & $\mathrm{p}<0.001$ (trend) & $\mathrm{p}<0.001$ (trend) & $\mathrm{p}<0.001$ (trend) \\
\hline \multicolumn{4}{|c|}{ Time since the last pre-qualificaiton exacerbation* } \\
\hline$<1$ year & $11.8 \%$ & $20.5 \%$ & $39.5 \%$ \\
\hline $1-2$ years & $8.8 \%$ & $11.0 \%$ & $22.3 \%$ \\
\hline $2-3$ years & $6.5 \%$ & $9.2 \%$ & $16.2 \%$ \\
\hline \multirow[t]{2}{*}{$3+$ years } & $1.9 \%$ & $5.8 \%$ & $13.6 \%$ \\
\hline & $\mathrm{p}<0.001$ (trend) & $\mathrm{p}<0.001$ (trend) & $\mathrm{p}<0.001$ (trend) \\
\hline
\end{tabular}

*Of the same type.

Discussion These results show that while few have hospital exacerbations, GP and prednisolone exacerbations are comparatively common. For all types, a previous and recent history of exacerbations increases the risk of future exacerbations.

\section{Challenges in smoking cessation P185 PUBLIC ATTITUDES TO SMOKING IN CARS}

doi:10.1136/thx.2010.151043.36

${ }^{1} \mathrm{E}$ De Lacy, ${ }^{1} \mathrm{R}$ Morrison, ${ }^{1} \mathrm{M}$ Dockrell, ${ }^{1} \mathrm{~T}$ Buchanan, ${ }^{2} \mathrm{~K}$ E Lewis. ${ }^{1}$ Action on Smoking and Health, England; ${ }^{2}$ Swansea University, Wales

Background Passive smoking is increasingly associated with adverse health effects. The new UK Government is considering its tobacco control policy.

Aim To record public attitudes on potential legislation regarding smoking in cars

Methods We commissioned a survey of the YouGov ${ }^{\circledR}$ Plc British panel of $185000+$ people (aged 18+). An email was sent to panellists, selected at random using a sophisticated sampling matrix, to be representative of each country. Three surveys were conducted between 25 and 30 March 2009. We obtained answers from $\mathrm{n}=10895$ adults in England, $\mathrm{n}=1023$ adults in Wales, and $\mathrm{n}=1157$ adults in Scotland. The results for all three countries were merged at analysis stage and re-weighted to be representative of the overall GB population. We had data from 13075 adults, 52\% female, mean age 
45.5 (range 18-88 years), 22\% of whom reported continued smoking at least occasionally.

Results Overall, $76 \%$ of adults support a ban on smoking in cars carrying children, $55 \%$ support a ban on smoking in cars carrying any passenger. Regarding a total ban on smoking in cars, $44 \%$ support a complete ban, with $37 \%$ opposing a complete ban and $19 \%$ were undecided. The Abstract P185 Table 1 shows responses by smoking status for support for a ban in cars.

\section{Abstract P185 Table 1}

\begin{tabular}{llll}
\hline & $\begin{array}{l}\text { Never or ex-smokers } \\
(\mathbf{n = 1 0 2 2 9 )}\end{array}$ & $\begin{array}{l}\text { Smokers } \\
(\mathbf{n = 2 8 4 6 )}\end{array}$ & p-Value \\
\hline $\begin{array}{l}\text { That are carrying children } \\
<18 \text { years of age }\end{array}$ & $81 \%$ & $58 \%$ & $<0.001$ \\
$\begin{array}{l}\text { That are carrying any } \\
\text { passenger }\end{array}$ & $64 \%$ & $24 \%$ & $<0.001$ \\
\begin{tabular}{l} 
All cars \\
\hline
\end{tabular} & $52 \%$ & $15 \%$ & $<0.001$ \\
\hline
\end{tabular}

Conclusions There remain differences in opinion between smokers and non-smokers but there appears widespread public support among both groups for a ban on smoking in cars, especially any carrying children.

\section{\begin{tabular}{|l|l}
\hline P186 PULIC ATTITUDES TO THE UK SMOKING BAN \\
\hline
\end{tabular}}

doi:10.1136/thx.2010.151043.37

${ }^{1} \mathrm{M}$ Dockrell, ${ }^{1} \mathrm{E}$ DeLacy, ${ }^{1} \mathrm{R}$ Morrison, ${ }^{1} \mathrm{~T}$ Buchanan, ${ }^{2} \mathrm{~K}$ E Lewis. ${ }^{1}$ Action on Smoking in Health, UK; ${ }^{2}$ School of Medicine, Swansea University, Swansea, UK

Aim To record public attitudes to the 2006-2007 UK bans on smoking in enclosed public and workplaces.

Methods We commissioned a survey of the YouGov Plc British panel of $185000+$ people (aged 18+). An email was sent to panellists, selected at random using a sophisticated sampling matrix, to be representative of each country. Three surveys were conducted between 25 and 30 March 2009. We obtained answers from $\mathrm{n}=10895$ adults in England, $\mathrm{n}=1023$ adults in Wales, and $\mathrm{n}=1157$ adults in Scotland. The results for all three countries were merged at analysis stage and re-weighted to be representative of the overall GB population. We had data from 13075 adults, $52 \%$ female, mean age 45.5 years (range 18-88 years), $22 \%$ of whom reported continued smoking at least occasionally.

Results Overall, $79.1 \%$ supported the ban, $14.6 \%$ opposed the ban and $6.2 \%$ were unsure. The Abstract P186 Table 1 describes responses by smoking status:

Table 1

\begin{tabular}{llll}
\hline & $\begin{array}{l}\text { Non-smokers } \\
\text { (n= 10229) }\end{array}$ & $\begin{array}{l}\text { Smokers } \\
\text { (n=2847) }\end{array}$ & p-value \\
\hline $\begin{array}{l}\text { Support for the ban } \\
\begin{array}{l}\text { The ban is good for the } \\
\text { health of most workers }\end{array}\end{array}$ & $88 \%$ & $47 \%$ & $<0.001$ \\
$\begin{array}{l}\text { The ban is good for the health } \\
\text { of the general public }\end{array}$ & $88 \%$ & $73 \%$ & $<0.001$ \\
\begin{tabular}{l} 
The ban is good for my own health \\
\hline
\end{tabular} & $86 \%$ & $61 \%$ & $<0.001$ \\
\end{tabular}

Conclusions There remain differences in opinion between smokers and non-smokers but public support for the ban on smoking in public and workplaces remains high. Most people (including smokers) believe the ban has significant beneficial health effects at all levels.

\section{P187 PARENTS SUPPORT BAN OF SMOKING IN CARS WHERE MINORS ARE PRESENT}

doi:10.1136/thx.2010.151043.38

I Jarrold, K Huntly, T Turkel, N Eiser. British Lung Foundation, London, UK

Introduction Passive smoking is particularly dangerous for children; it increases their risk of developing asthma and triggers asthmatic attacks. Methods This study sought information regarding parents' smoking habits and their attitude to smoking in front of their children from Mumsnet, an online social networking community for parents with over one million users.

Results 1020 people (97\% female, $2 \%$ male, $1 \%$ not specified) were surveyed online. Of the respondents, 770 had children $<5$ years, 365 had children $6-10$ years, 168 had children $11-15$ years while 64 respondents had children $\geq 16$ years. Twelve per cent respondents were current smokers, $42 \%$ ex-smokers, $45 \%$ never smokers and $1 \%$ did not specify. 939 respondents had partners, of whom $17 \%$ were current smokers, $37 \%$ ex-smokers and $46 \%$ never smokers. Of 553 respondents who were current or ex-smokers, $5 \%$ confessed to smoking with children present in the same room and $7 \%$ to smoking in a car containing children. 290 respondents had smoked in front of their children at some time. Of these, $4 \%$ thought that their children may develop a lung condition as a result while $5 \%$ thought that passive smoking would not affect their children's health. 17\% thought that their children may take up smoking as a result. While only $45 \%$ of all respondents would support a smoking ban in all private cars (whether or not a child was present), $86 \%$ would support a smoking ban in cars when a minor is present. Among current smokers, $83 \%$ would support a smoking ban in private cars with a minor present.

Conclusions This survey shows overwhelming support for a ban on smoking in cars where minors are present, even amongst current smokers. However, sadly it also revealed that $5 \%$ parents who had smoked in front of their children believed that this has no impact on that child. Further publicity campaigns are needed to promote both awareness of the risks of passive smoking and the need of legislature to ban smoking in private cars.

Abstract P187 Table 1 Support for smoking ban in private cars-all respondents (1020)

\begin{tabular}{lccccc}
\hline \multicolumn{7}{l}{ Support for smoking ban in all private cars } \\
\hline & Smoker & Ex-smoker & Never smoker & $\begin{array}{l}\text { Smoking status } \\
\text { not specified }\end{array}$ & Total \\
\hline Support ban & $37(29 \%)$ & $178(42 \%)$ & $239(52 \%)$ & $1(10 \%)$ & $455(45 \%)$ \\
Oppose ban & $71(56 \%)$ & $147(34 \%)$ & $123(27 \%)$ & $4(36 \%)$ & $345(34 \%)$ \\
Don't know & $19(15 \%)$ & $101(24 \%)$ & $94(21 \%)$ & $6(54 \%)$ & $220(22 \%)$ \\
Support for smoking ban in private cars when a minor is present & \\
Support ban & $106(83 \%)$ & $363(85 \%)$ & $398(87 \%)$ & $6(55 \%)$ & $867(86 \%)$ \\
Oppose Ban & $11(9 \%)$ & $26(6 \%)$ & $30(7 \%)$ & $0(0 \%)$ & $67(7 \%)$ \\
Don't know & $10(8 \%)$ & $37(9 \%)$ & $28(6 \%)$ & $5(45 \%)$ & $80(8 \%)$ \\
\hline
\end{tabular}

P188 AN EVALUATION OF A NOVEL SEMI-QUANTITATIVE SALIVA TEST FOR COTININE AND OTHER NICOTINIC METABOLITES

doi:10.1136/thx.2010.151043.39

${ }^{1} \mathrm{G}$ F Cope, ${ }^{2} \mathrm{G}$ V O'Donovan, ${ }^{1} \mathrm{~B}$ Savage, ${ }^{2} \mathrm{H} \mathrm{J}$ Milburn. ${ }^{1} \mathrm{GFC}$ Diagnostics Ltd, Bicester, UK; 'uy's and St Thomas' NHS Foundation Trust, London, UK

Background The accurate determination of smoking habit is important for the treatment of smoking-related disease. Cotinine, the major metabolite of nicotine is the analyte of choice to assess 